\title{
Enzymatic degradation behavior and cytocompatibility of silk fibroin-starch-chitosan conjugate membranes
}

\author{
Erkan T. Baran *, Kadriye Tuzlakoğlu, João F. Mano, Rui L. Reis
}

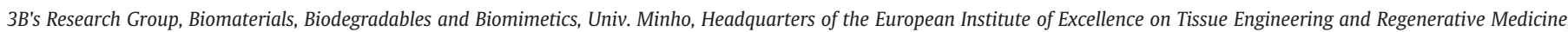
AvePark, S. Cláudio do Barco, 4806-909 Taipas, Guimarães, Portugal

ICVS/3B's PT Government Associate Laboratory, Braga/Guimarães, Portugal

\section{A R T I C L E I N F O}

\section{Article history:}

Received 31 January 2011

Received in revised form 24 September 2011

Accepted 2 February 2012

Available online 16 February 2012

\section{Keywords}

Biodegradation

Chitosan

Conjugation

Cytocompatibility

Starch

Silk fibroin

\begin{abstract}
A B S T R A C T
The objective of this study was to investigate the influence of silk fibroin and oxidized starch conjugation on the enzymatic degradation behavior and the cytocompatability of chitosan based biomaterials. The tensile stress of conjugate membranes, which was at 50 Megapascal (MPa) for the lowest fibroin and starch composition (10 weight percent (wt.\%)), was decreased significantly with the increased content of fibroin and starch. The weight loss of conjugates in $\alpha$-amylase was more notable when the starch concentration was the highest at $30 \mathrm{wt} . \%$. The conjugates were resistant to the degradation by protease and lysozyme except for the conjugates with the lowest starch concentration. After 10 days of cell culture, the proliferation of osteoblast-like cells (SaOS-2) was stimulated significantly by higher fibroin compositions and the DNA synthesis on the conjugate with the highest fibroin (30 wt.\%) was about two times more compared to the native chitosan. The light microscopy and the image analysis results showed that the cell area and the lengths were decreased significantly with higher fibroin/chitosan ratio. The study proved that the conjugation of fibroin and starch with the chitosan based biomaterials by the use of non-toxic reductive alkylation crosslinking significantly improved the cytocompatibility and modulated the biodegradation, respectively.
\end{abstract}

(c) 2012 Published by Elsevier B.V.

\section{Introduction}

The silk fibroin (SF) has been used clinically as a biocompatible suture material for decades and has gained a renewed interest as a scaffold for tissue engineering and a potentially useful biomaterial [1]. Recently, the fibroin was investigated as a controlled drug delivery matrix and coating material [2-5]. The tissue engineering potential was proved and applied for the cartilage, bone, ligament, skeletal tissue, blood vessel, adipose and nerve tissues [6,7]. The biocompatible properties of SF inspired scientific investigations to manipulate it to be used as biomaterials in different forms such as, the sponge, non-woven fiber mesh, nanofiber mat, membranes and hydrogel $[8,9]$.

There are fewer studies on the conjugates of fibroin with other biopolymers than its use as a pure biomaterial. In one of those studies, an oxidative enzyme, the tyrosinase, was used to oxidize the chitosan and coupled to SF [10]. The SF-conjugated N-acetyl-chito-oligosaccharides and SF-hyaluronic acid complexes were proposed as a wound dressing

\footnotetext{
* Corresponding author at: 3B's Research Group, Biomaterials, Biodegradables and Biomimetics, Univ. Minho, Headquarters of the European Institute of Excellence on Tissue Engineering and Regenerative Medicine, AvePark, S. Cláudio do Barco, 4806-909 Taipas, Guimarães, Portugal. Tel.: + 351253 510911; fax: + 351253510909.

E-mail addresses: erkantur@metu.edu.tr (E.T. Baran), kadriye@dep.uminho.pt (K. Tuzlakoğlu), jmano@dep.uminho.pt (J.F. Mano), rgreis@dep.uminho.pt (R.L. Reis).
}

material and for applying in biomedical fields, respectively [11-13]. In addition, small functional group additions, like the sulfation of SF by chlorsulfonic acid and the lactose group conjugation with SF, have been investigated to obtain as an anti-coagulant and fibrogenic biomaterials, respectively [14,15].

The rate of human mesenchymal cell proliferation was found higher on silk films than either on a collagen or a tissue culture plate [16]. Also, the growth of various anchorage depended cells showed similar growth rate both on the fibroin- and the collagen-coated plates, and it was $30-50 \%$ higher than it was on the polystyrene plates coated with hydrophilic groups [17]. In addition, in a recent study, it was proved that SF blending with polysaccharides (chitosan and hyaluronic acid) to mimic the extracellular matrix (ECM) increased the viability and the growth rate of rat mesenchymal stem cells significantly in relative to the cell culture plate [18]. The physiological reasons and biochemical properties for this enhanced growth of cells on SF have not been well revealed in comparison with other matrix proteins used in cell culture. Nevertheless, the fibroin based biomaterials may find wide spread applications in animal cell culture technology for the production of monoclonal antibodies and pharmaceutical recombinant proteins instead of using mammalian origin proteins as a substratum.

The chitosan, which is a linear polysaccharide composed of $\beta(1-4)$ linked D-glucosamine and $\mathrm{N}$-acetyl D-glucosamine residues, was used in this study as a polysaccharide matrix for the conjugation of fibroin and starch. The chitosan, is regarded as biocompatible, non cytotoxic 
and processable into many physical forms for biomedical uses [19-22]. On the other hand, despite their good attachment, anchorage dependent cells, including the osteoblast-like cells, were not able to proliferate effectively on the casted or electro spun chitosan substrates [23]. Furthermore, the slow degradation of chitosan in vivo can limit its application in tissue engineering field [24].

The starch, a linear polymer of $\alpha$-(1-4) glucose units with periodic branches of $\alpha-(1-6)$ linkages, is an abundant, inexpensive, biocompatible biomaterial and may increase the biodegradation capacity of other biomaterials significantly when it is incorporated $[25,26]$. The potential of starch as a sustained release matrix was also notified $[27,28]$. In addition, the chemically modified and grafted starches have been recently used in drug delivery application $[29,30]$. Furthermore, the starch blended with poly(ethylene-co-vinyl alcohol) and poly(capro lactone) biomaterials have also indicated their potential as bone tissue engineering scaffolds [31,32].

In this study, novel chitosan based biomaterials were prepared by the incorporation of fibroin and starch for the purpose of increased cytocompatibility and controlled biodegradability, respectively. Even though fibroin is very biocompatible, the brittleness, due to its high crystalline structure, is undesirable and limiting its use as biomaterials $[4,33]$. Therefore, the conjugate materials of fibroin with ductile and biocompatible polysaccharides can bring novel biomaterials, which have the positive sides of biopolymers used. In this work, we focused to functionalize chitosan matrix by the conjugation of readily biodegradable starch macromolecule, which can be hydrolyzed by $\alpha$-amylase and may improve degradation in vitro and in potential in vivo applications. At the same time, the incorporation of aldehyde-starch (made by the non-toxic periodate oxidation) can be used as a natural crosslinker as it crosslink the macromolecules which have primary amine groups. In this study, we hypothesized that the conjugation of silk fibroin and starch into chitosan based biomaterials would increase both biodegradation and cell compatibilities, which are important requirements of cell supporting matrixes intended for tissue engineering field. Therefore, the degradation behaviors, the rate of cell proliferation over the conjugate materials and cytocompatibility were tested.

\section{Material and methods}

\subsection{Materials}

Chitosan (deacetylation degree 87\%, medium molecular weight, approximately $250 \mathrm{kDa}$ ), acetic acid, sodium hydroxide, sodium periodate, lysozyme (EC 3.2.1.17, from hen egg white) and protease (EC 3.4.24.31, type XIV from Streptomyces griseus) were obtained from Sigma Chemical Co. (St. Louis, USA). The soluble starch from potato origin was obtained from ATO (Wageningen, The Netherlands). The soluble starch used in this study was shown to have an average molecular weight around $291 \mathrm{kDa}$ and have a gyration radius of $24 \mathrm{~nm}$ as analyzed with laser light-scattering technique [34]. $\alpha$-Amylase (EC 3.2.1.1, from Bacillus amyloliquefaciens) was gently supplied by Genencor International, Inc. (Rochester, NY, USA). All the other chemicals used herein were of analytical grade. Bombyx mori silk bells were used as raw material and obtained from Halcyon Yarn Inc. (Bath, USA).

\subsection{Purification of silk fibroin}

The silk fibroin used in this study was purified according to method developed by Yamada et al. [35]. To remove its sericin component (natural glue that fixing silk fibers), $B$. mori silk raw material was immersed 3 times in $0.05 \% \mathrm{Na}_{2} \mathrm{CO}_{3}$ for $30 \mathrm{~min}$ at $98{ }^{\circ} \mathrm{C}$ to $100{ }^{\circ} \mathrm{C}$. The resulting fibroin fibers ( $35 \mathrm{~g}$ fibroin) were dissolved in a solution of $\mathrm{CaCl}_{2}$ :ethanol:water $(226.4 \mathrm{~g} \mathrm{CaCl} 2,346 \mathrm{~mL}$ distilled water, and $280 \mathrm{~mL}$ ethanol) at $78 \pm 2{ }^{\circ} \mathrm{C}$ with stirring. The mixture was filtered and dialyzed against distilled water for 3 days to yield a concentrated silk fibroin solution.

\subsection{Conjugate membrane preparation}

The membranes of silk fibroin, starch (oxidized for aldehyde generation) and chitosan were prepared at different weight percentages by mixing a proper ratio of each compound and casting the mixture into a Petri dish for drying. The conjugation of three biopolymers was performed by reductive alkylation crosslinking as explained in our previous study [25]. The oxidation of soluble starch was performed according to the procedure described by Hermanson et al. [36]. Briefly, soluble starch was dissolved in distilled water $(20 \mathrm{mg} /$ $\mathrm{mL}$ ) by mixing in a light protected glass vessel. Then, $0.125 \mathrm{~mL}$ of sodium iodate solution $(10 \mathrm{mg} / \mathrm{mL}$ ) was added for each $\mathrm{mL}$ of starch solution while mixing the solution. The reaction proceeded for $30 \mathrm{~min}$ by mixing the solution at room temperature. In order to quench the reaction, $0.1 \mathrm{~mL}$ glycerin/ $\mathrm{mL}$ of reaction medium was added and mixed for $10 \mathrm{~min}$ before blending with a chitosan solution.

The fibroin $(20 \mathrm{mg} / \mathrm{mL})$ and the oxidized starch solution $(15.22 \mathrm{mg} / \mathrm{mL})$ were blended with the chitosan $(1 \% \mathrm{w} / \mathrm{v}$, in $1 \%$ acetic acid) solution in a glass vessel by vortex mixing in various weight percentage (wt.\%) compositions. The sample compositions and their abbreviations are shown in Table 1. The blended preparation at defined composition, which had a total polymer weight of $200 \mathrm{mg}$, was casted into a square polystyrene Petri plate $\left(25 \mathrm{~cm}^{2}\right)$. Plates were subsequently allowed to dry for several days at room temperature without light. After drying, a solution of bicarbonate buffer $(0.5 \mathrm{M}, \mathrm{pH} 8.5)$ was poured over the membranes inside petri dishes and incubated for $3 \mathrm{~h}$ so that the conjugation between the reactive aldehyde groups of starch and the primary amino groups of chitosan to be formed by imine linkage. Afterwards, the membranes were washed several times with distilled water and incubated with aqueous sodium borohydride $\left(\mathrm{NaBH}_{4}\right)(0.05 \%)$ solution for 1 in order to reduce the excess, uncrosslinked aldehyde groups and to convert the imine conjugation into the covalent bond. Finally, after washing several times with distilled water, the membranes were allowed to dry on the same Petri dishes at room temperature.

For comparison, chitosan membranes were prepared by casting a solution (1\%) into Petri dishes and drying them at room temperature. The stabilization of chitosan membranes were achieved by soaking the membranes into a $\mathrm{NaOH}$ solution $(1 \mathrm{~N})$ and neutralizing for $2 \mathrm{~h}$. The fibroin membranes were prepared by casting a solution $(20 \mathrm{mg} / \mathrm{mL}$, $5 \mathrm{~mL}$ ) into polystyrene dishes (diameter $=5.5 \mathrm{~cm}$ ) and incubating the dried membranes with a methanol solution $(80 \% \mathrm{v} / \mathrm{v}$, diluted with distilled water) for $1 \mathrm{~h}$. The obtained fibroin membranes, however, were too brittle to handle or to cut them into proper pieces. Therefore, the fibroin films could be tested only in cell culture experiments.

\subsection{The mechanical characterization of membranes}

The conjugate membranes were subjected to tensile tests to evaluate the effect of fibroin and starch ratio over the mechanical

Table 1

Composition (weight percentage, wt.\% ) of conjugate membranes prepared from fibroin (F), starch (S) and chitosan (C).

\begin{tabular}{llll}
\hline $\begin{array}{l}\text { Sample abbreviation } \\
\text { (F: fibroin; S: starch; } \\
\text { C: chitosan.) }\end{array}$ & \multicolumn{3}{l}{ Fibroin-starch-chitosan weight percentages (wt.\%) } \\
\cline { 2 - 4 } & $\left(\mathrm{wt}_{\text {fibroin }} / \mathrm{wt}_{\text {starch }} / \mathrm{wt}_{\text {chitosan }}\right)$ & Chitosan \\
\cline { 2 - 4 } & Fibroin & Starch & 80 \\
\hline F10/S10/C80 & 10 & 10 & 70 \\
F15/S15/C70 & 15 & 15 & 55 \\
F30/S15/C55 & 30 & 15 & 55 \\
F15/S30/C55 & 15 & 30 & 40 \\
F30/S30/C40 & 30 & 30 &
\end{tabular}


properties of membranes. The dry membranes were cut into rectangles (20 mm length, $5 \mathrm{~mm}$ width) and the thickness of each individual membrane was measured (the average thickness of membranes were about $20 \mu \mathrm{m}$ ). The tensile tests were performed at room temperature in a Universal Mechanical Test Machine (Instron 4505) using a crosshead speed of $5 \mathrm{~mm} \cdot \mathrm{min}^{-1}$ and grip distance of $18 \mathrm{~mm}$. The tensile strength was taken as the maximum stress of the stress-strain curve at break. The tensile modulus was evaluated using the maximum slope of the stress-strain curve. A minimum of five specimens were tested for each sample type.

\subsection{In vitro biodegradation of conjugates in $\alpha$-amylase, protease and lysozyme solutions}

Separately, each membrane piece (100 mg dry weight) of conjugate material at defined wt.\% composition was put into falcon tube containing $40 \mathrm{~mL}$ phosphate buffered saline (PBS, Sigma, USA) solution with $\alpha$-amylase $\left(\mathrm{pH} 7.4,37^{\circ} \mathrm{C}, 150 \mathrm{IU} / \mathrm{mL}\right)$. The $\alpha$-amylase solution was changed weekly with a fresh preparation. For lysozyme and protease degradation studies, the membrane piece at defined composition ( $45 \mathrm{mg}$ ) was placed into a falcon tube containing the respective enzyme solution ( $500 \mathrm{IU} / \mathrm{mL}$ lysozyme or $1 \mathrm{IU} / \mathrm{mL}$ protease in $15 \mathrm{~mL}$ PBS, pH 7.4). The solution of protease and lysozyme $(15 \mathrm{~mL})$ was replaced daily with a freshly prepared solution. Also, the neutralized chitosan membranes were incubated in solutions of lysozyme, protease and PBS (in the case of non-enzymatic weight loss determination) for comparison with the conjugates since chitosan is known to be hydrolyzed by those enzymes non-specifically $[24,37,38]$. The membranes were collected at predetermined time points and the excess solution was removed from the surface by using a tissue paper. The collected samples at defined time points were weighed by using an analytical balance with $\pm 0.1 \mathrm{mg}$ accuracy. After the equilibration time of swelling in PBS $(1 \mathrm{~h})$, the measured wet weight of sample was considered as the initial wet weight (100\%).

\subsection{FT-IR spectral analysis}

A separate set of conjugate membranes of the ternary conjugates at wt.\% values of 15, 15, 70 (F15/S15/C70) and 15, 30, 55 wt.\% (F15/S30/C55), were incubated in an $\alpha$-amylase solution as explained in the biodegradation study. Since the enzyme is expected to act on starch molecules, these two sample compositions, which represent a lower (15\%) and a higher starch (30\%) wt.\% composition, were chosen in order to investigate and compare the changes in absorption bands due to the hydrolysis by $\alpha$-amylase. The incubated samples were collected at predetermined time points and washed thoroughly with distilled water. After drying at room temperature, the membranes were analyzed by a FT-IR spectrometer (Shimadzu, IR Prestige-21) between $2000 \mathrm{~cm}^{-1}$ and $700 \mathrm{~cm}^{-1}$ with a resolution of $4 \mathrm{~cm}^{-1}$, using the $\mathrm{KBr}$ pellet method. The results are presented as the average of 32 scans.

\subsection{In vitro cell culture for cytocompatibility evaluation}

To evaluate the influence of silk fibroin/starch content on cell attachment and proliferation, a human osteoblast-like cell line (SaOS-2) was selected for cell culture experiments. The present study used the human osteosarcoma cell line SaOS-2 because it is established, well characterized and the spreading morphology and the cell area on the surface are sensitive to different materials [39]. The membranes were cut into pieces $\left(1 \mathrm{~cm}^{2}\right)$, sterilized with $70 \%$ ethanol (15 $\mathrm{min})$ and placed into the cell culture plates after drying. Subsequently, $1 \mathrm{~mL}$ of cell suspension containing $5 \times 10^{4}$ cells in a culture medium (DMEM low glucose supplemented with 10\% Fetal Bovine Serum and $1 \%$ antibiotics/antimycotics) were dropped onto membranes. The cells on membranes were then allowed to grow until 10 days at $37{ }^{\circ} \mathrm{C}$ in humidified atmosphere containing $5 \% \mathrm{CO}_{2}$ with medium changes every 2 days.

After each time points (3, 7 and 10 days), the collected samples were rinsed with PBS and then fixed in 2.5\% glutaraldehyde for morphological examination. They were dehydrated through graded of series of ethanol and dried in room temperature. The samples were mounted on the brass stubs with an attached carbon tape and they were sputter coated with gold under vacuum. Finally, the samples were analyzed under a scanning electron microscope (SEM) (Leica Cambridge S360 microscope) at an acceleration voltage of $15 \mathrm{kV}$.

PicoGreen ${ }^{\circledR}$ dsDNA kit (Molecular Probes, USA) was used to quantify DNA content of the cell/membrane construct in order to evaluate the cell proliferation. The PicoGreen ${ }^{\circledR}$ dsDNA Quantization Reagent is an ultra-sensitive fluorescent nucleic acid stain for quantitative analysis of double-stranded DNA (dsDNA) in solutions. To perform this assay, the samples $(n=3)$ were taken after each time points and rinsed with PBS. They were then put into microtubes with $1 \mathrm{~mL}$ of ultra pure water and incubated $1 \mathrm{~h}$ at $37^{\circ} \mathrm{C}$ before freezing at $-80^{\circ} \mathrm{C}$ for overnight. In the end of the experiment, the all collected samples were thawed and put in an ultrasonic bath for $15 \mathrm{~min}$. An aliquot of each sample was transferred to a 96-well plate. A certain ratio of Tris-EDTA buffer and PicoGreen ${ }^{\circledR}$ reagent prepared in the same buffer was added to the each well. The fluorescence was measured at $485 \mathrm{~nm}$ excitation and $528 \mathrm{~nm}$ emission wavelengths. The DNA amount of each samples was then calculated using a standard curve.

The cellular viability and cell spreading analysis were further assessed by using the vital dye calcein-AM (acetoxymethyl diacetylester of calcein). This vital dye is internalized by viable cells and converted into a green fluorescent impermeable dye due to the action of active intracellular esterases. After each time points, the samples were incubated for $10 \mathrm{~min}$ in a medium supplemented with $0.1 \mu \mathrm{M}$ calcein-AM. Then, they were mounted in the mounting medium Vectorshield $₫$ (Vector, UK) and visualized by a confocal laser scanning microscope (Olympus IX81). For quantitative image analysis, the images were captured at a constant magnification and ImageJ Java image analyzer software (National Institute of Health, USA, version $1.38 \times$ ) was used for average cell length and cell area measurements. In this analysis, high resolution images were transformed into 8-bit images and a micrograph of the scale of calibration slide at the same magnification was used to calibrate the software. At least 100 separate cells at the surface of samples $(n=3)$ were processed for the measurement of area and length.

\subsection{Statistical analysis}

Unless otherwise indicated, the quantitative results were acquired from triplicate samples. The data were expressed as means and the error bars show the standard deviation (S.D). The statistical analysis for cell area and length was carried out by using the unpaired Student's $t$-test, and a value of ${ }^{*} P<0.05$ was considered statistically significant.

\section{Results and discussion}

In this study, the conjugates of starch and fibroin with chitosan at various wt.\% were produced for modulating the degradation in the presence of physiological enzymes and improving cytocompatibility. The degradation profile was monitored over prolonged time periods and the chemical changes during degradation periods were investigated by using spectroscopic methods. In vitro cell culture studies were performed for analyzing the cell proliferation and adhesion behaviors on the conjugates. 


\subsection{The mechanical characterization of membranes}

The fibroin-starch-chitosan conjugate membranes were tested mechanically to investigate the effect of starch and fibroin incorporation on the strength of membranes. In general, the tensile strength of membranes was lowered by increasing the starch composition and leveled off at a modulus of around $1500 \mathrm{MPa}$ (Table 2). As indicated in Table 2, for the conjugate membranes with the lowest starch composition (10\%) the average tensile stress was approximately $50 \mathrm{MPa}$. For $15 \mathrm{wt} . \%$ and the highest starch composition (30 wt.\%) membranes, however, the maximum stresses were changed between $40 \mathrm{MPa}$ and $30 \mathrm{MPa}$.

As shown by the mechanical tests, the conjugate membranes became weaker by increasing the fibroin and starch content when they are compared with the $\mathrm{NaOH}$ neutralized chitosan membranes, which showed a maximum tensile stress of $53 \mathrm{MPa}$ and a modulus of $2070 \mathrm{MPa}$. Our previous study proved that the starch incorporation impaired the strength of starch-chitosan conjugate membranes considerably [25]. Likewise, Kolhe et al. indicated that poly(ethylene glycol) blending with chitosan gave rise to some decrease in mechanical strength of films, increase in ductility and the loss of semi-crystalline structure of chitosan [40]. As a conclusion, the decreased level of order of chitosan matrix by adding starch and fibroin might decrease the mechanical strength of conjugate biomaterials.

From strain values in Table 2 and representative stress-strain curves of conjugate membranes (Fig. 1) it is apparent that with decreasing chitosan content the elongation or strain of property of conjugate membranes decreased. The average strain $\left(1 / l_{0}\right)$ of conjugate membranes with the highest chitosan composition (80\%) and the lowest chitosan ( $40 \%$ ) were 0.088 and 0.032 , respectively. It can be also expected from higher starch compositions that increased rate of crosslinking by aldehydes of starch made the conjugates more brittle and less elastic.

\subsection{In vitro biodegradation of conjugates in $\alpha$-amylase, protease and lysozyme solutions}

One of the main aims of this study was to characterize the biodegradation behavior of biomaterials produced by the conjugation of silk fibroin and starch into chitosan matrix, using a non-toxic chemical conjugation method (e.g. reductive alkylation chemistry). The unit activity and the source organism of $\alpha$-amylase, protease and lysozyme used in the degradation models were selected on the basis of prior experiments which were described in the literature [25,37,41]. As seen in Fig. 2, the weight loss or the degradation rate of fibroin-starchchitosan conjugate membranes in $\alpha$-amylase solution was depended on the starch composition. The membranes with 10 and $15 \mathrm{wt} . \%$ starch composition showed no significant change in their residual masses after two months. For the membranes with $30 \mathrm{wt} . \%$ starch (F15/S30/C55 and F30/S30/C40), on the other hand, approximately 20 and 50\% weight loss were observed, respectively. The rate of weight loss in both preparations was faster after one week of incubation period in the enzyme solution.

As expected, the conjugates with the highest starch compositions showed more weight losses in $\alpha$-amylase solution. The compositions

Table 2

The modulus, maximum tensile stress and strain at break values of conjugate fibroinstarch-chitosan membranes with various compositions $\left(n=5\right.$, temperature $\left.22{ }^{\circ} \mathrm{C}\right)$.

\begin{tabular}{llll}
\hline $\begin{array}{l}\text { Sample (F: fibroin; } \\
\text { S: starch; C: chitosan.) }\end{array}$ & $\begin{array}{l}\text { Modulus (E) } \\
(\mathrm{MPa})\end{array}$ & $\begin{array}{l}\text { Maximum } \\
\text { stress }(\mathrm{MPa})\end{array}$ & $\begin{array}{l}\text { Strain at } \\
\text { break }\left(\Delta \mathrm{L} / \mathrm{L}_{\mathrm{o}}\right)\end{array}$ \\
\hline F10/S10/C80 & $1500 \pm 931.4$ & $51.54 \pm 12.83$ & $0.088 \pm 0.029$ \\
F15/S15/C70 & $1338 \pm 547.6$ & $29.41 \pm 16.81$ & $0.059 \pm 0.030$ \\
F30/S15/C55 & $1533 \pm 139.6$ & $39.11 \pm 6.660$ & $0.056 \pm 0.014$ \\
F15/S30/C55 & $1940 \pm 302.3$ & $34.76 \pm 17.15$ & $0.030 \pm 0.015$ \\
F30/S30/C40 & $1466 \pm 298.1$ & $32.00 \pm 9.010$ & $0.032 \pm 0.012$ \\
\hline
\end{tabular}

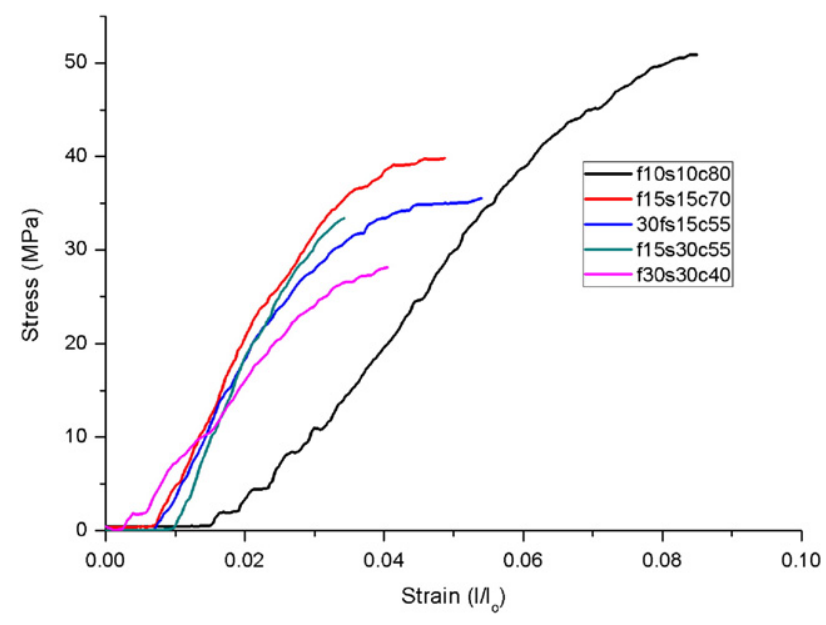

Fig. 1. Representative stress-strain curves of fibroin-starch-chitosan conjugate membranes with different weight ratio.

with lower percentage of starch practically did not indicate degradation during two months in $\alpha$-amylase solution. This can be due to a limited availability of starch chains to the enzyme's active site after an extensive crosslinking between the aldehydes of starch and the primary amino groups, which were provided mainly from chitosan matrix.

The weight loss profiles obtained by protease and lysozyme incubations indicated no significant reduction in their residual weights except for the conjugate with the lowest starch concentration (F10/S10/C80) and the chitosan membrane. As noticed in Fig. 3, at the end of 3 weeks of protease incubation, the residual weight of chitosan membrane was near $78 \%$ while this was about $95 \%$ for the conjugate with the lowest fibroin and starch composition (F10/C10/C80). In PBS solution alone, which was tested for determination of non-enzymatic weight loss, the $\mathrm{NaOH}$ stabilized chitosan membranes did not indicate a significant weight loss (data not shown). Except for the lowest starch composition (10 wt.\%) sample and the chitosan membrane, it was also detectable that the wet weight of conjugate membranes were above $100 \%$ due to a further water uptake in extended periods.

It was shown before that the chitosan can be degraded by protease and lysozyme activity [37,22]. Accordingly, the chitosan membranes showed significant weight losses in both enzyme solutions. Once

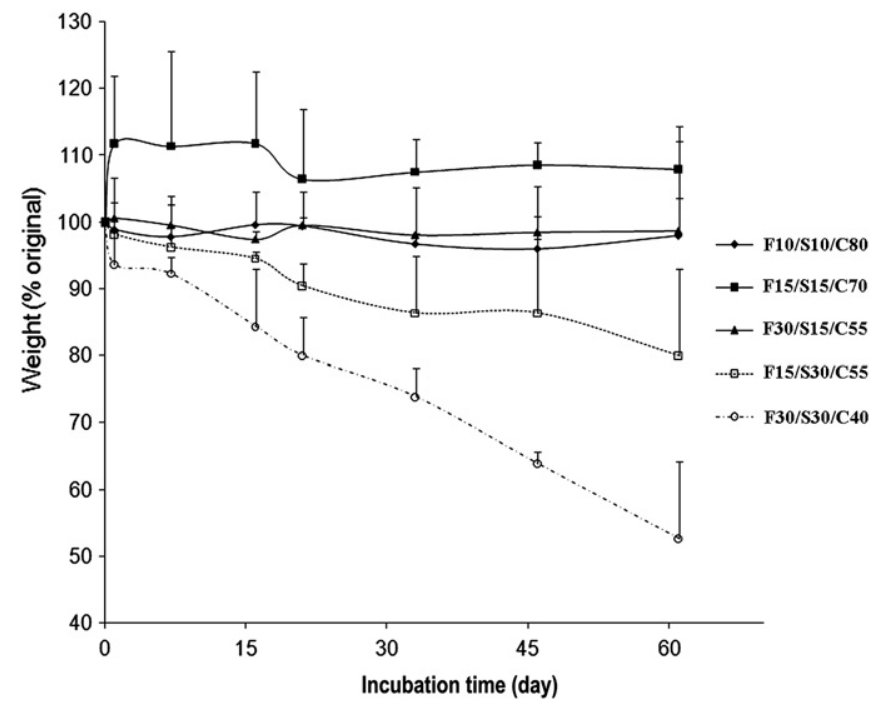

Fig. 2. Weight changes of fibroin-starch-chitosan conjugate membranes with various weight ratios in the presence of $\alpha$-amylase $\left(37^{\circ} \mathrm{C}, 150 \mathrm{U} / \mathrm{mL}\right)$. 


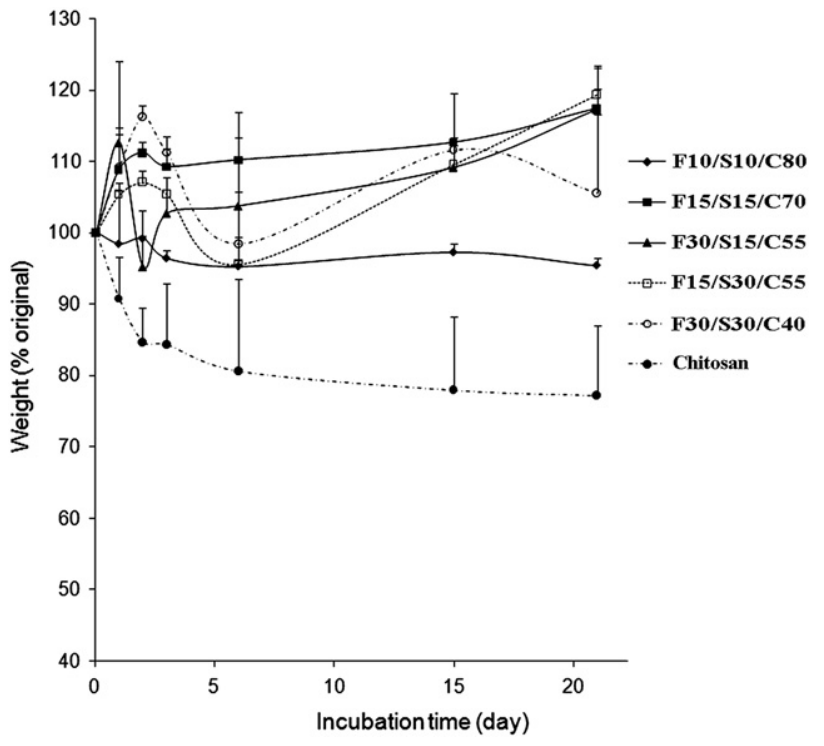

Fig. 3. Weight changes of fibroin-starch-chitosan conjugate membranes with different weight ratio in the presence of protease $\left(37^{\circ} \mathrm{C}, 1 \mathrm{IU} / \mathrm{mL}\right.$, with daily changes of enzyme solution).

again, the excessive crosslink between the aldehyde of starch and amine groups of other biopolymers must be the main reason for impaired enzyme activities over the conjugate membranes.

The conjugate biomaterials showed a further swelling during the initial days of protease incubation. The protease activity directed to chitosan and the fibroin molecules could facilitate swelling due to the chain scission by hydrolysis, in which additional functional groups are formed at the cleaved ester site. It was reported before that low molecular weight chitosan (LMWC) was formed during the non-specific hydrolysis of chitosan by proteases rather than producing the soluble oligomers which can be formed by the specific catalysis of chitinases [42]. The extensive crosslinking of those biopolymers with aldehyde-starch within conjugate membrane might prevent the leaching out of the LMWC which can increase water uptake.

Similar to the results from protease test, the lysozyme treatment was effective on the neutralized chitosan membrane (Fig. 4). None of the conjugates exhibited a significant weight loss during three

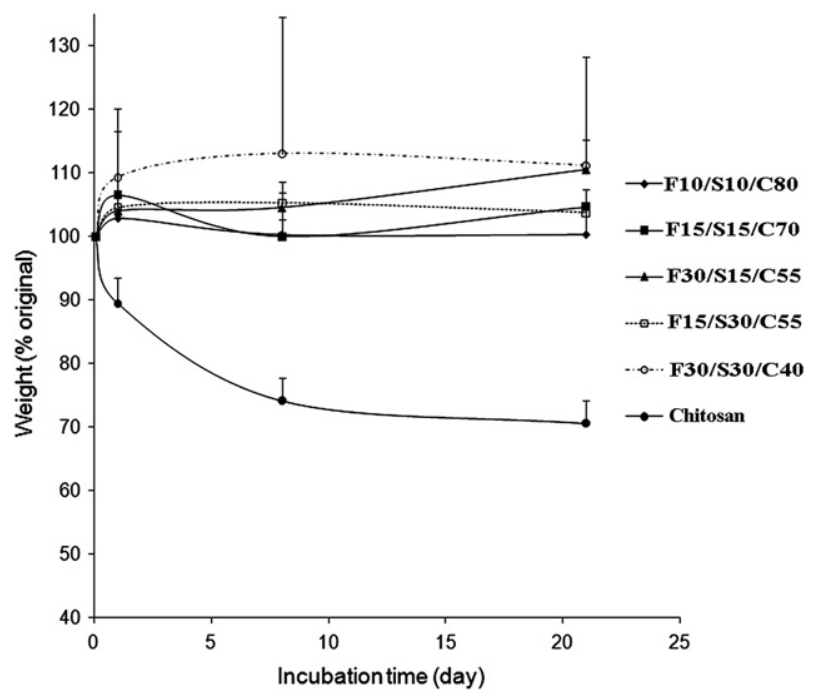

Fig. 4. Weight changes of fibroin-starch-chitosan membranes with different weight ratio in the presence of lysozyme $\left(37^{\circ} \mathrm{C}, 500 \mathrm{IU} / \mathrm{mL}\right.$, with daily changes of enzyme solution). weeks of lysozyme incubation. It is well known that, in human body, $\mathrm{N}$-acetylated chitosan is mainly depolymerised enzymatically by hydrolyzing action of lysozyme on the glycosidic bonds present in its chemical structure [43]. The lysozyme contains a hexameric binding site [44], a hexasaccharide sequence that presents 3-4 or more acetylated units, necessary for the initial degradation of $\mathrm{N}$-acetylated chitosan [45]. The crosslinking of chitosan with starch units might interfere with this binding condition of lysozyme. Consequently an incomplete mode of action can be expected from this steric hindrance. Therefore, the slight swelling of conjugates observed during initial days in the lysozyme solution could be due to an increased water uptake by the partial hydrolysis of chitosan, similar to the results from protease test.

\subsection{FT-IR spectral analysis}

The enzymatic degradation of conjugate materials was more pronounced in $\alpha$-amylase solution. Therefore, a FT-IR analysis was performed for the monitoring of changes in the absorption bands of the samples incubated in that enzyme solution for certain time. The FT-IR spectrum of the conjugate at lower starch F15/S15/C70 and higher starch F15/S30/C55 composition, as well as the native biopolymers, are shown in Fig. 5(a), (b) and (c), respectively. Chitosan and fibroin present the bands at $1633 \mathrm{~cm}^{-1}$ due to amide I and $1314 \mathrm{~cm}^{-1}$ due to amide III. The broad peak at $1076 \mathrm{~cm}^{-1}$, which is attributed to the $\mathrm{C}-\mathrm{O}$ stretching vibration in chitosan, was differentiated and become more apparent as degradation time was increased (Fig. 5(b)) [46]. In starch, the band between 923 and $1162 \mathrm{~cm}^{-1}$, attributed to the $\mathrm{C}-\mathrm{O}$ bond stretching, was detected at $1155 \mathrm{~cm}^{-1}$ [47]. Although the amide band at $1220 \mathrm{~cm}^{-1}$ was more distinct after two weeks, the intensity of band at $1540-1571 \mathrm{~cm}^{-1}$ from low starch membrane was not changed significantly except the last week (Fig. 5(a)). This amide band from high starch membranes was more distinguished As the degradation period of $\alpha$-amylase was extended (Fig. 5(b)). The amide band at $1220 \mathrm{~cm}^{-1}$ of F15/S30/C55 was appeared after 3rd week and intensified at 4th week (Fig. 5(b)). For the membrane with higher starch content, the $\mathrm{C}-\mathrm{O}$ stretching band $\left(1076 \mathrm{~cm}^{-1}\right)$ from chitosan and amide bands were more significant along with prolonged incubation. The increase of amide band and $\mathrm{C}-\mathrm{O}$ stretching band intensity of chitosan must be due to a specific degradation of starch by $\alpha$-amylase and hence, the relative increase of chitosan and fibroin ratio which are contributing to absorbencies.

\subsection{In vitro cell culture for cytocompatibility evaluation}

In vitro cell culture studies were conducted to evaluate the biocompatibility and proliferation capacities of conjugate materials. At defined time points of culture, the DNA content of anchored cells on membranes was measured for assessing their cell proliferation potential. The cell morphologies, such as the area and maximum length, were measured and quantified over a large population of cells in order to characterize cell adhesion behavior. The viability assay based on the use of the fluorescent vital dye calcein-AM showed that the SaOS-2 cells on conjugate membranes were as viable as the cells on native chitosan and fibroin membrane which were not crosslinked chemically. The fluorescence light transmission microscope analysis highlighted the presence of green (the sign of viability) and anchored cells over the surface of all samples studied. Similar results were also detected for the samples which were cultured for 7 and 10 days (data not shown). From those results it can be concluded that the conjugation process did not produce any toxic product or chemical group that can decrease the cell viability over time. In recent studies, it was shown also that human mesencyhmal stem cells presented flat and elongated cell morphologies and growth of bovine chondrocytes and the phenotypic expression were supported by blended silk fibroin and chitosan scaffolds $[48,49]$. 

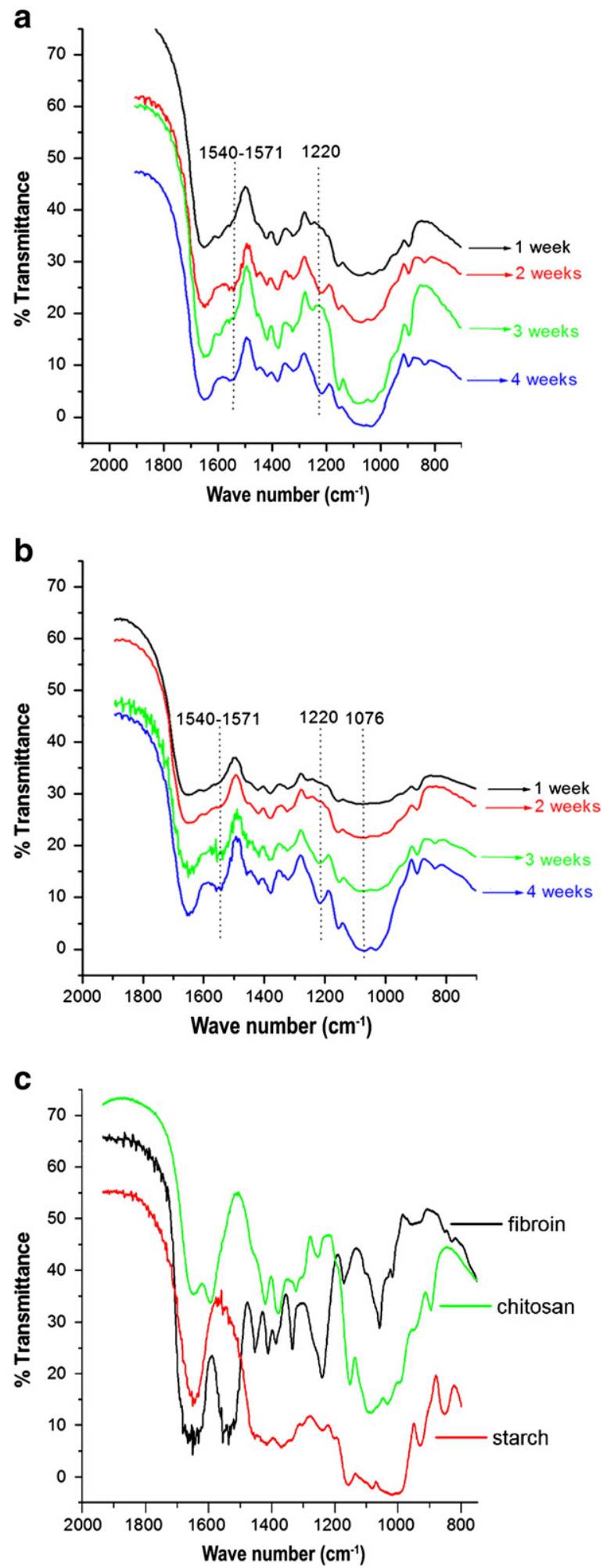

Fig. 5. The FT-IR spectrum changes of membranes of F15/S15/C70 (a) and F15/S30/C55 (b) after various $\alpha$-amylase incubation periods.

When compared in their DNA quantities, which were synthesized by the growing cells on membranes, the conjugate biomaterials containing a higher fibroin composition presented better cell proliferation behavior, especially in late culture periods. After the incubation of cells for three days, there was no significant difference between the DNA content of chitosan and conjugate biomaterials except for the content from pure fibroin, which was slightly higher than the

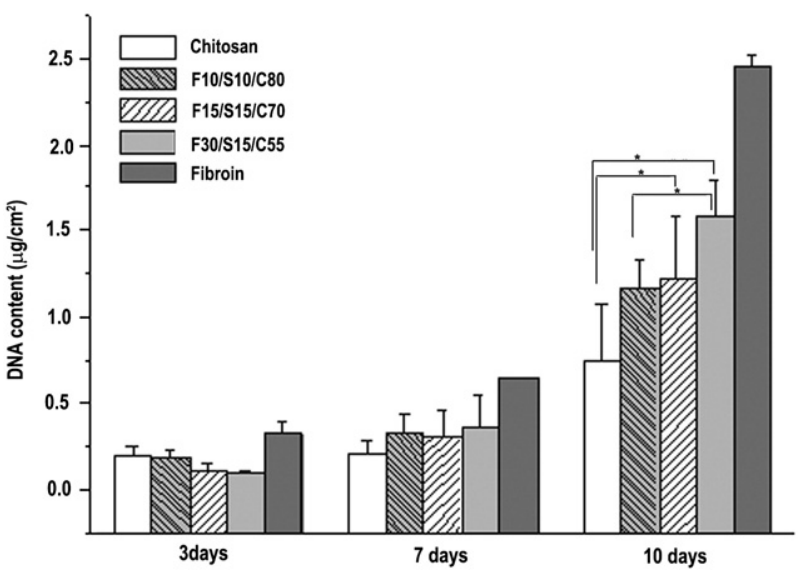

Fig. 6. The DNA quantities $\left(\mu \mathrm{g} / \mathrm{cm}^{2}\right)$ of conjugate membranes measured at different cell culture time points. The cell seeding density: $5 \times 10^{4} \mathrm{cells} / \mathrm{cm}^{2}$. The error bars indicate the standard deviation $(\mathrm{n}=3)$. Unpaired Student $t$ test, ${ }^{*} P<0.05$.

others (Fig. 6). After 7 days, the conjugate materials presented a slightly higher DNA when compared to the production from chitosan. At day 10, the DNA quantity from conjugate materials was significantly $(\mathrm{p}<0.05)$ higher than the quantity from chitosan and it was gradually increased with higher fibroin composition. The conjugate with the highest fibroin composition ( $30 \mathrm{wt} . \%$ ), the pure fibroin and the chitosan membrane exhibited a DNA concentration of about 1.6, 2.4 and $0.74 \mu \mathrm{g} / \mathrm{cm}^{2}$, respectively. In other words, the DNA synthesis on the conjugate with the highest fibroin (30 wt.\%) was increased
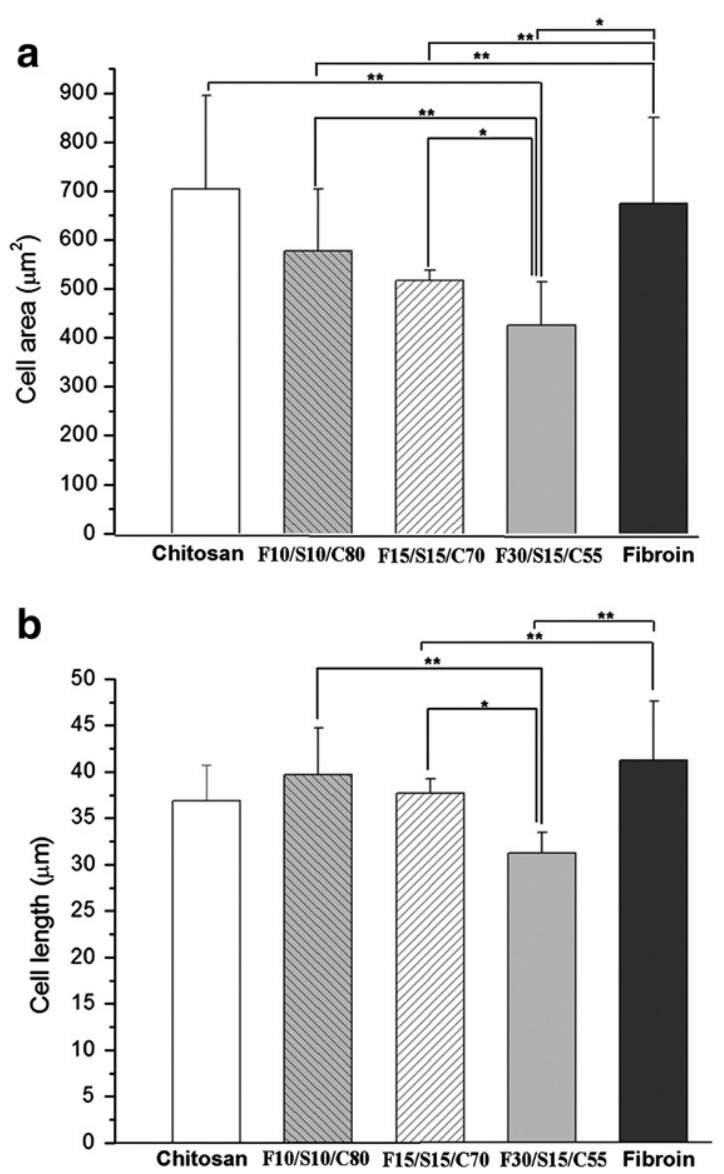

Fig. 7. The mean cell area (a) and maximum cell length (b) of SaOS-2 cells on chitosan, fibroin and fibroin-starch-chitosan conjugate membranes after 3 days of culture. The error bars indicate the standard deviation $(\mathrm{n}=3)$. Unpaired Student $t$ test, ${ }^{*} P<0.05$ or ${ }^{* *} P<0.01$. 


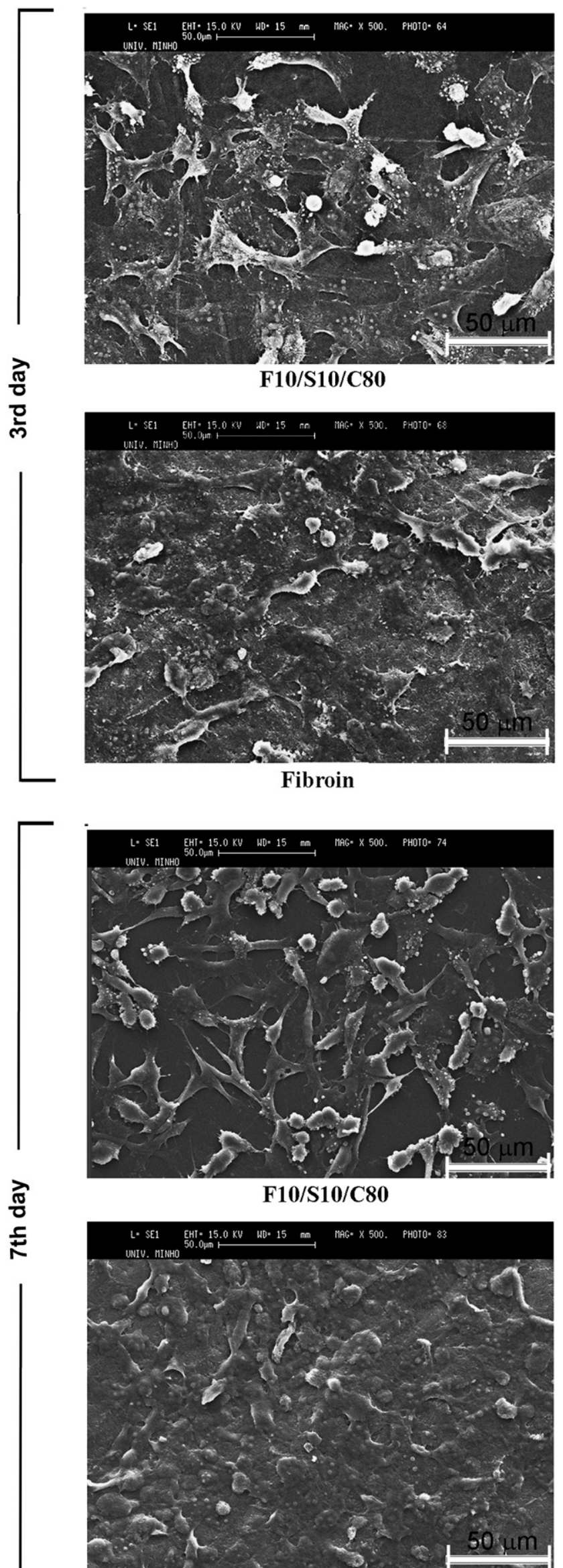

Fibroin

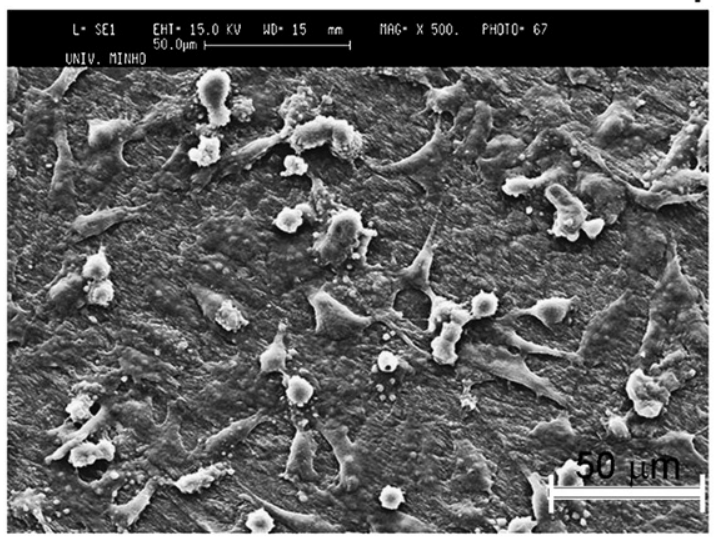

F30/S15/C55

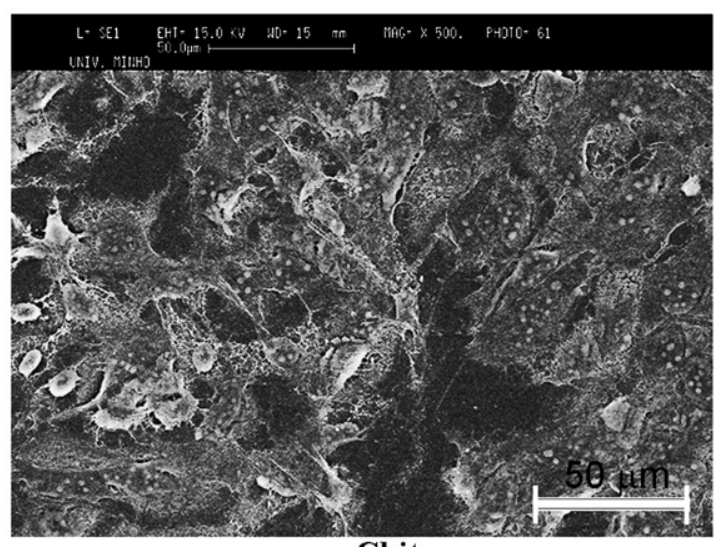

Chitosan

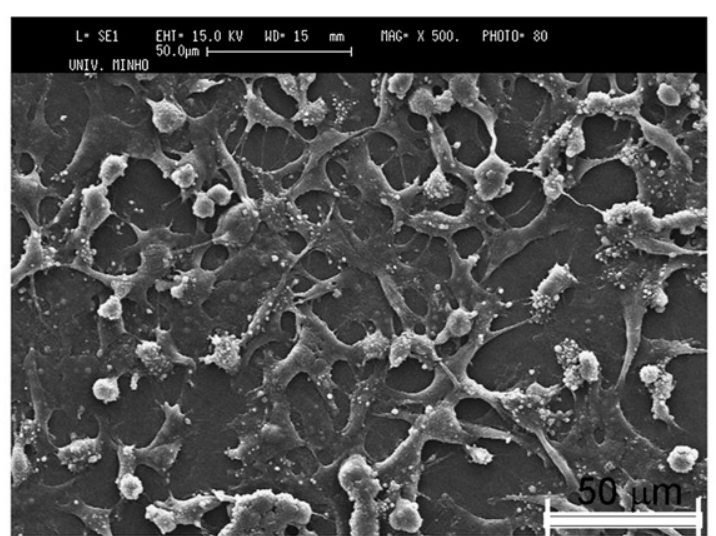

F30/S15/C55

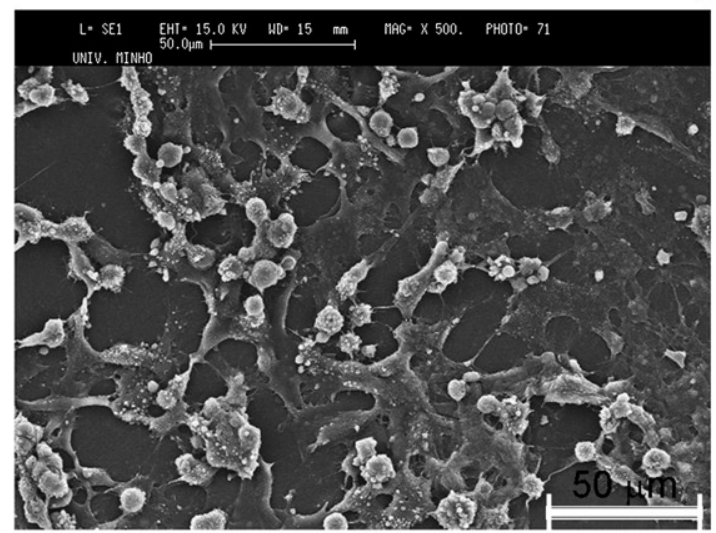

Chitosan

Fig. 8. The scanning electron microphotographs of SaOS-2 cells on the conjugate, fibroin and chitosan membrane surfaces (scale bar is $50 \mu \mathrm{m}$ ) 
about 2.1 times compared to the synthesis on the native chitosan membrane.

The significant increase of DNA content with higher fibroin concentrations at late time points of cell culture proved that the conjugation of fibroin improved the cytocompatibility of conjugate materials. In a previous study, it was reported that the proliferation efficiency of cells on the fibroin was similar or more than the proliferation on collagen and tissue culture plates [7]. Moreover, the extensive growth and spreading of human cell lines over the fibers of non-woven nets indicated that the fibroin fibers are highly humancell compatible [17]. Unlike the results in our study, however, silk fibroin-hyaluronic acid composites showed enhanced chondrocyte ingrowth into silk fibroin/hyaluronan scaffolds and DNA synthesis as compared to plain silk fibroin scaffolds [18]. This result may indicate that the cell type and the type of polysaccharide blended with silk fibroin may affect DNA expression levels nonlinearly. In a similar study in the literature, slight increase in the metabolic rate of rat mesanchymal stem cells on SF/chitosan or SF/chitosan-hyaluronic acid also supporting the hypothesis that the growth of certain cell phenotypes were affected positively by blending fibroin with polysaccharides [50].

The level of cell spreading on conjugates was studied in order to characterize the cell-biomaterials interface interaction. The fluorescence light micrographs of cells adhered on the membrane surface were taken and evaluated by the image analyzer software. As seen in Fig. 7(a) and (b), the unique cell features were presented by each type of conjugate composition. The presence of low chitosan concentration or higher level of fibroin and starch composition resulted in a significant decrease of cell area and cell lengths. In general, the cells on pure fibroin and chitosan had a higher cell area than those from the conjugates. The cell area on the chitosan and the fibroin surfaces were about 700 and $600 \mu \mathrm{m}^{2}$, respectively (Fig. 7(a)). In the case of conjugates, however, the cell area was decreased from $600 \mu \mathrm{m}^{2}$ to $400 \mu^{2}$ gradually with higher fibroin compositions (significantly with 15 and 30 wt.\%, p <0.01). Likewise, as presented in Fig. 7(b)a, a similar trend in cell length was observed when the fibroin composition of conjugates were increased gradually. The cell lengths were reduced significantly (from 40 to $30 \mu \mathrm{m}$ ) by increasing the composition of fibroin from 10 to $30 \mathrm{wt} . \%(\mathrm{p}<0.01)$ and 15 to $30 \mathrm{wt} . \%$ $(\mathrm{p}<0.05)$. In addition, the SEM micrographs further elucidated that the cells spread on the surface of chitosan extensively with smooth cell membrane morphology. On the conjugate membranes, on the other hand, the cells presented a rough membrane and numerous filopodias were apparent (Fig. 8).

It was detected that the cell area and length were sensitive to the variations of composition in conjugate materials. Although a larger cell area and cell length were induced by the surface of chitosan and fibroin membranes, for the conjugates, however, those values were significantly lower and decreased gradually with increasing fibroin/chitosan ratio. This may reflect the cationic nature of chitosan, onto which a negatively charged cell membrane can adhere by electrostatic forces; consequently, spread more on the surface. The results from quantitative cell morphology analysis suggest that the larger cell area due to a cationic charge contribution from chitosan might not affect the cell proliferation positively. Although the cell attachment on the surfaces of biomaterials is very important for cell viability and proliferation, too strong attachment and having a very large spreading area might not create optimum conditions for cellular events like the migration and mitotic cell division.

The SEM micrographs presented spread cell morphology on the surface of chitosan membrane and a relatively smooth cell membrane was evident. The cells on conjugate materials, on the other hand, showed a rougher cell membrane and the filopodial projections, which is an indication of active cell migration [51]. Those results may suggest that the SaOS-2 cells were in increased cellular activities such as the cellular migration and the matrix deposition, as a result of a favorable biochemical environment provided by fibroin and starch conjugation.

\section{Conclusion}

In this study, the oxidized starch and silk fibroin were cocrosslinked into chitosan matrix by using the non-toxic reductive alkylation procedure in order to modulate biodegradation by physiologic enzymes and increase cytocompatibility of chitosan based biomaterials. The conjugates with higher starch content showed significant weight loss profiles in $\alpha$-amylase while the conjugates with lower starch exhibited resistance to the enzyme activity. The protease and lysozyme activities were effective only on the conjugates with the lowest starch and fibroin compositions. The increase of fibroin composition in conjugates was found highly effective in increasing cell proliferation capacities at late time period as seen by the doubling of DNA production at the highest fibroin composition in comparison with the native chitosan. Moreover, the cell area and length were found to be sensitive to variations in conjugate composition significantly and they were inversely correlated with the increase of fibroin and decrease of chitosan concentration. The results from this study suggest that the biodegradation and cell proliferation properties of hydrophilic biopolymers can be customized by conjugating fibroin and starch at different ratios. It can be further envisaged that the developed conjugates can be used for a variety of tissue engineering constructs, which require different degree of biodegradation and cell adsorption properties depending on the site of implanting.

\section{Acknowledgments}

E.T. Baran thanks the Portuguese Foundation for Science and Technology for providing him a PostDoc scholarship (SFRH/BPD/ $30768 / 2006$ ). This work was partially supported by the European Union funded STREP Project HIPPOCRATES (NMP3-CT-2003-505758).

\section{References}

[1] G.H. Altman, F. Diaz, C. Jakuba, T. Calabro, R.L. Horan, J. Chen, H. Lu, J. Richmond, D.L. Kaplan, Biomaterials 24 (2003) 401.

[2] P.C. Bessa, E.R. Balmayor, H.S. Azevedo, S. Nürnberger, M. Casal, M. van Griensven, R.L. Reis, H. Redl, J. Tissue Eng. Regen. Med. 4 (2010) 349.

[3] X. Wang, X. Hu, A. Daley, O. Rabotyagova, P. Cebe, D.L. Kaplan, J. Controlled Release 121 (2007) 190.

[4] G.M. Nogueira, A.C.D. Rodas, C.A.P. Leite, C. Giles, O.Z. Higa, B. Polakiewicz, M.M. Beppu, Bioresour. Technol. 101 (2010) 8446.

[5] L. Uebersax, M. Mattotti, M. Papaloïzos, H.P. Merkle, B. Gander, L. Meinel, Biomaterials 28 (2007) 4449.

[6] J.G. Hardy, L.M. Römer, T.R. Scheibel, Polymer 49 (2008) 4309.

[7] C. Vepari, D.L. Kaplan, Prog. Polym. Sci. 32 (2007) 991.

[8] J.G. Hardy, T.R. Scheibel, Prog. Polym. Sci. 35 (2010) 1093.

[9] G.H. Altman, F. Diaz, C. Jakuba, T. Calabro, R.L. Horan, J. Chen, H. Lu, J. Richmond, D.L. Kaplan, Biomaterials 24 (2003) 401.

[10] S. Sampaio, P. Taddei, P. Monti, J. Buchert, G. Freddi, J. Biotechnol. 116 (2005) 21.

[11] Y. Gotoh, N. Minoura, T. Miyashita, Colloid Polym. Sci. 280 (2002) 568.

[12] Y. Gotoh, M. Tsukada, Polymer 38 (1997) 487.

[13] O. Malay, A. Batigun, O. Bayraktar, Int. J. Pharm. 380 (2009) 120.

[14] Y. Tamada, Biomaterials 25 (2004) 377.

[15] C. Acharya, B. Hinz, S.C. Kundu, Biomaterials 29 (2008) 4665.

[16] L. Meinel, S. Hofmann, V. Karageorgiou, C. Kirker-Heade, J. McCoole, G. Gronowicz, L. Zichner, R. Langer, G. Vunjak-Novakovic, D.L. Kaplan, Biomaterials 26 (2005) 147.

[17] R.E. Unger, M. Wolf, K. Peters, A. Motta, C. Migliaresi, C.J. Kirkpatrick, Biomaterials 25 (2004) 1069.

[18] M. Garcia-Fuentes, A.J. Meinel, M. Hilbe, L. Meinel, H.P. Merkle, Biomaterials 30 (2009) 5068.

[19] M. Patel, L. Mao, B. Wu, P.J. Vandevord, J. Tissue Eng. Regen. Med. 1 (2007) 360.

[20] S.S. Silva, B.J. Goodfellow, J. Benesch, J. Rocha, J.F. Mano, R.L. Reis, Carbohydr. Polym. 70 (2007) 25.

[21] K. Tuzlakoglu, R.L. Reis, J. Mater. Sci.:Mater. Med. 18 (2007) 1279.

[22] I.B. Leonor, E.T. Baran, M. Kawashita, R.L. Reis, T. Kokubo, T. Nakamura, Acta Biomater. 4 (2008) 1349.

[23] P. Sangsanoh, O. Suwantong, A. Neamnark, P. Cheepsunthorn, P. Pavasant, P. Supaphol, Eur. Polym. J. 46 (2010) 428.

[24] K. Tomihata, Y. Ikada, Biomaterials 16 (1997) 567.

[25] E.T. Baran, J.F. Mano, R.L. Reis, J. Mater. Sci.:Mater. Med. 15 (2004) 759. 
[26] A. Serrero, S. Trombotto, P. Cassagnau, Y. Bayon, P. Gravagna, S. Montanari, L. David, Biomacromolecules 11 (2010) 1534.

[27] F.O. Onofre, Y.J. Wang, Int. J. Pharm. 385 (2010) 104.

[28] T. Nabais, F. Brouillet, S. Kyriacos, M. Mroueh, P. Amores da Silva, B. Bataille, C. Chebli, L. Cartilier, Eur. J. Pharm. Biopharm. 65 (2007) 371.

[29] A.P. Vieira, P. Ferreira, J.F.J. Coelho, M.H. Gil, Int. J. Biol. Macromol. 43 (2008) 325.

[30] J.A. Marinich, C. Ferrero, M.R. Jiménez-Castellanos, Eur. J. Pharm. Biopharm. 72 (2009) 138.

[31] I. Pashkuleva, P.M. López-Pérez, H.S. Azevedo, R.L. Reis, Mater. Sci. Eng. C 30 (2010) 981.

[32] T.C. Santos, A.P. Marques, B. Höring, A.R. Martins, K. Tuzlakoglu, A.G. Castro, M. van Griensven, R.L. Reis, Acta Biomater. 6 (2010) 4314

[33] M. Li, S. Lu, Z. Wu, K. Tan, N. Minoura, S. Kuga, Macromolecules 30 (2002) 89.

[34] I. Simkovic, M. Hricovıni, R. Mendichi, J.J.G. van Soest, Carbohydr. Polym. 55 (2004) 299.

[35] H. Yamada, H. Nakao, Y. Takasu, K. Tsubouchi, Mater. Sci. Eng. C 14 (2001) 41.

[36] G.T. Hermanson, Bioconjugate Techniques, Academic Press, 1996, p. 116.

[37] R.L. Horan, K. Antle, A.L. Collette, Y. Wang, J. Huang, J.E. Moreau, V. Volloch, D.L. Kaplan, G.H. Altman, Biomaterials 26 (2005) 3385.

[38] T. Kean, M. Thanou, Adv. Drug Deliv. Rev. 62 (2010) 3.
[39] A. Okumura, M. Goto, T. Goto, M. Yoshinari, S. Masuko, T. Katsuki, T. Tanaka, Biomaterials 22 (2001) 2263.

[40] P. Kolhe, R.M. Kannan, Biomacromolecules 4 (2003) 173.

[41] N. Nwe, T. Furuike, H. Tamura, Materials 2 (2009) 374.

[42] A.B.V. Kumar, R.N. Tharanathan, Carbohydr. Polym. 58 (2004) 275.

[43] K.M. Varum, M.M. Myhr, R.J.N. Hjerde, O. Smidsrod, Carbohydr. Res. 299 (1997) 99.

[44] S.H. Pangburn, P.V. Trescony, J. Heller, Biomaterials 3 (1982) 105

[45] R.J. Nordtveit, K.M. Varum, O. Smidsrod, Carbohydr. Polym. 23 (1994) 253.

[46] S. Mathew, M. Brahmakumar, T.E. Abraham, Biopolymers 82 (2006) 176.

[47] S.M. Goheen, R.P.J. Wool, Appl. Polym. Sci. 42 (1991) 2691.

[48] A.M. Altman, V. Gupta, C.N. Ríos, E.U. Alt, A.B. Mathur, Acta Biomater. 6 (2010) 1388-1397.

[49] N. Bhardwaj, Q.T. Nguyen, A.C. Chen, D.L. Kaplan, R.L. Sah, S.C. Kundu, Biomaterials 32 (2011) 5773.

[50] M.C. Yang, S.S. Wang, N.K. Chou, N.H. Chi, Y.Y. Huang, Y.L. Chang, M.J. Shieh, T.W. Chung, Biomaterials 30 (2009) 3757.

[51] P.K. Mattila, P. Lappalainen, Nat. Rev. Cell Biol. 6 (2008) 446. 